\title{
LIABILITI BAGI PENIPUAN TORT DALAM FORENSIK*
}

\section{Liability for Tort of Deceit in Forensic}

\author{
Nurbazla Ismail ${ }^{1}$ \\ Abdul Basir Mohamad ${ }^{2}$
}

\begin{abstract}
Deceit is one branch of the offense under tort law. Deceit can be said to be a fraud act committed by someone who caused the other party to suffer loss or injury. The party suffering a loss or an injury can bring a claim in court on the basis of the tort law. Besides, the claimant must proof several important things before the court can decide the liability. This proof or evidence requires scientific verification by forensic experts. The testimony of the forensic expert can be used to convict deception and also can be used to dismiss the case in court. However, some forensic evidence is wrongly given in the trial. This has a significant effect on both the claimant and the defendant. As a result, the question arises as to what is the liability for tort of deceit in forensic according to tort and Islamic law. The purpose of this study is to define the meaning of deceit in tort and Islamic law as well as the liability for tort of deceit in forensic. This is a case study which
\end{abstract}

* Penyelidikan ini dibiayai oleh Kementerian Pengajian Tinggi Malaysia Fundamental Research Grant Scheme (FRGS) FRGS/1/2017/SS06/UKM/03/2.

1 Lecturer, Centre for Syariah Research, Faculty of Islamic Studies, Universiti Kebangsaan Malaysia, 43600 Bangi, Malaysia, nurbazla@ukm.edu.my

2 Professor, Centre for Syariah Research, Faculty of Islamic Studies, Universiti Kebangsaan Malaysia, 43600 Bangi, Malaysia, abasir@ukm.edu.my 
gathered materials based on literature reviews, including cases published in Malaysian legal journals as well as cases addressed by fuqaha. The study was analyzed using thematic and descriptive methods. The study found that deceit is an offense according to tort and Islamic law. The liability for tort of deceit by a forensic expert must be determined on the grounds of which the deceit was knowingly committed while testifying to the evidence before the court. This study has implications to the judiciary; legal practitioners in Malaysia and to the forensic experts who were called to adduce evidence in court.

Keywords: tort of deceit, deceit in Islamic law, deceit in forensic, forensic evidence, fraud, liability in tort of deceit

\section{PENGENALAN}

Penipuan secara umumnya merupakan satu perbuatan atau tindakan salah yang menyebabkan penganiayaan berlaku kepada pihak yang ditipu. Tindakan salah ini biasanya dikaitkan dengan disiplin ilmu seperti psikiatri. Namun, terdapat juga perkaitan dengan ilmu lain seperti perakaunan, ketenteraan, perhubungan, undang-undang perubatan dan pengamalan forensik. ${ }^{3}$ Tindakan salah ini boleh terjadi dalam pelbagai situasi, sama ada dalam aspek jual beli, urusan pejabat dan dalam urusan harian lain ${ }^{4}$ yang menyebabkan salah satu pihak teraniaya disebabkan penipuan tersebut. Dari sudut undang-undang, penipuan banyak digunakan dalam undang-undang kontrak. Walau bagaimanapun, penipuan boleh juga dikaitkan dengan undang-undang tort dan undang-undang jenayah.

Namun, dalam perbincangan ini, penipuan dalam undang-undang kontrak dan undang-undang jenayah tidak akan dijelaskan kerana kajian ini memfokuskan kepada penipuan dalam undang-undang tort (tort of deceit). Selain itu, perbincangan ini akan menjelaskan penipuan dalam perundangan Islam dan penipuan dalam forensik. Dalam perundangan Islam, penipuan merupakan satu tindakan salah yang sangat dilarang, termasuklah dalam undang-undang tort. Penipuan dalam undang-undang tort adalah satu kecederaan atau kerosakan yang diiktiraf dalam undang-undang disebabkan oleh seseorang yang berniat menipu dan mengetahui akan kesalahan tersebut tetapi tetap melakukan penipuan.

$3 \quad$ Spence, S. A., 'Reading about Deception,' The Psychiatrist, vol. 34 (2010): 146149.

4 Abdul Basir Mohamad, Undang-undang Tort Islam (Kuala Lumpur: Dewan Bahasa dan Pustaka, 2009), 2-3. 
Contohnya, penipuan dalam tuntutan insurans. Terdapat pihak yang menipu untuk mendapatkan keuntungan dalam urusan insurans dengan melakukan kecelakaan dengan sengaja, membuat tuntutan palsu terhadap kemalangan atau kecederaan yang tidak pernah berlaku, menipu tentang berlakunya kematian untuk mendapatkan bayaran manfaat insurans hayat atau mengemukakan tuntutan kematian palsu dan pelbagai jenis penipuan lagi yang menyebabkan kerugian kepada pihak yang lain.

Kebanyakan urusan kehidupan manusia pada masa kini menggunakan teknologi, maka ini akan membuka ruang untuk berlaku penyalahgunaan atau penipuan dalam urusan tersebut. Kepesatan teknologi ini menjadikan bidang forensik semakin berkembang. Penggunaan teknologi dalam bidang forensik juga semakin diperlukan terutamanya dalam sistem undang-undang. Bidang forensik semakin penting kepada badan kehakiman dan undang-undang kerana perkhidmatan pakar forensik dalam keadaan tertentu adalah diperlukan dalam proses pembuktian kesalahan sama ada untuk mensabitkan pesalah dengan hukuman ataupun untuk membebaskan pesalah.

Dalam perundangan Islam, pihak yang ditipu boleh menuntut ganti rugi terhadap kerugian yang dialaminya akibat daripada tindakan penipuan oleh seseorang. Hal ini berdasarkan kata-kata Ibn Qayyim al-Jawziyyah, ${ }^{5}$ seorang fuqaha mazhab sunni bahawa penipuan boleh menimbulkan asas ganti rugi tanpa mengira dilakukan dalam apa bentuk sekalipun. Contohnya dalam kes baju lama yang diwarnakan baru supaya kelihatan baru. Pihak yang mendakwa ditipu perlu mengemukakan bukti bahawa baju tersebut merupakan baju lama yang telah diwarnakan supaya kelihatan baru. Pakar forensik perlu dipanggil untuk mengesahkan perkara tersebut.

Begitu juga dalam undang-undang tort, pihak yang mengalami kerugian atau kecelakaan akibat daripada penipuan boleh membuat tuntutan di mahkamah berasaskan undang-undang common law dengan merujuk kepada kes-kes dan keputusan mahkamah yang diputuskan sebelum ini. Bagi membantu mahkamah membuktikan kesalahan penipuan ini, maka pakar forensik perlu dipanggil untuk memberikan keterangan. Contohnya dokumen palsu yang dikemukakan di mahkamah. Pembuktian dokumen tersebut memerlukan keterangan oleh pakar forensik dokumen. Pakar forensik ini akan mengesahkan sama ada dokumen yang dikemukakan adalah asli atau palsu.

5 Ibn Qayyim al-Jawziyyah, I'lām al-Muwaqqi 'īn 'an Rabb al-'Ālamīn, vol. 2 (Qāhirah: Dār al-Kutub al-Ḥadīthah, 1969), 158. 
Pakar forensik menurut undang-undang boleh dikatakan sebagai seorang pakar yang akan disapinakan ke mahkamah ${ }^{6}$ sekiranya terdapat apa-apa perkara yang memerlukan penjelasan oleh pakar forensik itu. ${ }^{7}$ Selain itu, kehadiran pakar adalah perlu kerana pihak-pihak dalam mahkamah berkemungkinan akan bertanya soalan berkaitan laporan analisis sesuatu bahan bukti. ${ }^{8}$ Seperti dalam kes pemalsuan dokumen, pakar forensik dokumen perlu melakukan analisis di makmal bagi mengenal pasti ketulenan sesuatu dokumen. Oleh itu, kehadiran pakar tersebut ke mahkamah adalah penting untuk mempertahankan laporan bukti tersebut dan untuk memperjelaskan mana-mana kekeliruan fakta dalam laporan tersebut.

Namun, terdapat kemungkinan bahawa berlaku penipuan oleh pakar forensik yang hadir memberikan keterangan dalam mahkamah. Perkara ini memberikan kesan yang besar sama ada kepada plaintif atau kepada defendan. Contohnya dalam kes pemalsuan dokumen, pakar forensik dokumen yang membuat analisis di makmal akan dipanggil untuk memberikan keterangan menjelaskan kesahihan dokumen tersebut. Keterangan pakar forensik boleh digunakan untuk membantu mensabitkan kesalahan dan boleh juga untuk menggugurkan kes dalam mahkamah. Sekiranya pakar forensik itu memberikan keterangan palsu atau keterangan yang berpihak kepada pihak yang membayarnya sehingga menyebabkan dakwaan salah, maka kemungkinan akan berlaku kesilapan dalam penghakiman kes tersebut.

Justeru, timbul beberapa persoalan yang menjadikan kajian ini relevan untuk dikaji iaitu bagaimanakah tanggungan bagi kesalahan penipuan dalam forensik sama ada dalam undang-undang tort atau perundangan Islam? Bagi mengenal pasti tanggungan bagi penipuan dalam forensik, maka adalah wajar untuk dijelaskan terlebih dahulu maksud penipuan dalam undang-undang tort dan perundangan Islam. Penipuan dalam forensik boleh dituntut di bawah undang-undang tort dan boleh juga dituntut berdasarkan perundangan Islam. Oleh itu, kajian ini dibuat untuk menjelaskan maksud penipuan menurut undang-undang tort dan perundangan Islam serta mengenal pasti bagaimana liabiliti penipuan dalam forensik.

6 Wall, W. Forensic Science in Court: The Role of the Expert Witness (United Kingdom: Wiley-Blackwell, 2009), 38.

7 Eckert, W. G. Introduction to Forensic Sciences, ed. Eckert, W. G. (New York: Elsevier, 1992), 34.

8 Wall, W. Forensic Science in Court: The Role of the Expert Witness, 34. 


\section{PENIPUAN MENURUT UNDANG-UNDANG MALAYSIA DAN PERUNDANGAN ISLAM}

Penipuan mempunyai maksud yang luas dan pelbagai merangkumi pelbagai jenis kesalahan dalam pelbagai keadaan dan situasi. Oleh itu, perbincangan seterusnya akan memperincikan maksud penipuan menurut undang-undang tort dan perundangan Islam.

\section{Penipuan dalam Undang-Undang Malaysia}

Penipuan merupakan kausa tindakan bagi tuntutan dalam undang-undang tort. Maksud bagi perkataan penipuan tidak disebut secara khusus dalam akta khusus dalam undang-undang tort. Oleh itu, adalah perlu untuk dikenal pasti maksud perkataan penipuan secara umum terlebih dahulu sebelum meneliti maksud yang terdapat di bawah peruntukan undang-undang khususnya di Malaysia. Penipuan (deceit) bermaksud mengelirukan; ${ }^{9}$ tindakan menyebabkan seseorang menerima sebagai benar atau sah apa yang salah atau tidak sah: ${ }^{10}$ perbuatan atau amalan menipu; ${ }^{11}$ percubaan atau alat untuk menipu: tipu daya; ${ }^{12}$ kualiti tidak jujur atau mengelirukan; ${ }^{13}$ kualiti menipu: tipu daya. ${ }^{14}$ Selain perkataan deceit, penipuan juga disebut sebagai fraud. Fraud berasal dari Bahasa Inggeris iaitu fraude dan dari bahasa Latin iaitu fraus. Fraud bermaksud penipuan, ${ }^{15}$

9 Shorter Oxford English Dictionary, $5^{\text {th }}$ ed., vol. 1 (United States: Oxford University Press, 2002), 614.

10 Merriam-Webster, https://www.merriam-webster.com/dictionary/fraud, dicapai pada 22 Julai 2019; The World Book Dictionary, vol. 1 (Chicago, United States of America: World Book, Inc. 2000), 536.

11 Merriam-Webster, https://www.merriam-webster.com/dictionary/fraud, dicapai pada 22 Julai 2019; The World Book Dictionary, vol. 1, 536.

12 Merriam-Webster, https://www.merriam-webster.com/dictionary/fraud, dicapai pada 22 Julai 2019.

13 Merriam-Webster, https://www.merriam-webster.com/dictionary/fraud, dicapai pada 22 Julai 2019; Shorter Oxford English Dictionary. 5 ${ }^{\text {th }}$ ed., vol. 1, 614; The World Book Dictionary, vol. 1, 536.

14 Merriam-Webster, https://www.merriam-webster.com/dictionary/fraud, dicapai pada 22 Julai 2019; Shorter Oxford English Dictionary, 5 ${ }^{\text {th }}$ ed., vol. 1, 614.

15 Merriam-Webster, https://www.merriam-webster.com/dictionary/fraud, dicapai pada 22 Julai 2019; Dictionary.com, https://www.dictionary.com/browse/fraud, dicapai pada 22 Julai 2019; The World Book Dictionary, vol. 1, 536. 
perbuatan atau amalan menipu, ${ }^{16}$ tipuan, ${ }^{17}$ alat untuk menipu, ${ }^{18}$ kualiti untuk menipu, ${ }^{19}$ tipu muslihat, ${ }^{20}$ kualiti untuk berlaku tidak jujur atau mengelirukan, ${ }^{21}$ dilakukan untuk mendapatkan keuntungan atau untuk memperoleh kelebihan yang tidak adil atau tidak jujur, ${ }^{22}$ perisytiharan palsu, ${ }^{23}$ pelanggaran keyakinan, ${ }^{24}$ satu perbuatan menyebabkan seseorang untuk menerima sebagai benar atau sah apa yang salah atau tidak sah. ${ }^{25}$ Perkataan-perkataan ini menjelaskan bahawa deceit dan fraud mempunyai maksud yang sama iaitu perbuatan menipu.

Manakala sumber undang-undang sering menggunakan istilah penipuan secara lebih luas meliputi maksud bukan sahaja berbohong, tetapi juga penyembunyian, kegagalan untuk mendedahkan, dan kesalahan lain. ${ }^{26}$ Penipuan menurut undang-undang juga bermaksud penyembunyian fakta yang disengajakan dan mengelirukan, mencuri secara penipuan, juga tort penipuan iaitu melakukan atau menjalankan suatu tindakan untuk menipu. ${ }^{27}$ Berdasarkan maksud penipuan secara umum dan dari sudut undang-undang, maka boleh disimpulkan bahawa penipuan adalah melakukan atau menjalankan

16 Merriam-Webster, https://www.merriam-webster.com/dictionary/fraud, dicapai pada 22 Julai 2019; Shorter Oxford English Dictionary. $5^{\text {th }}$ ed., vol. 1, 1028.

17 Merriam-Webster, https://www.merriam-webster.com/dictionary/fraud, dicapai pada 22 Julai 2019; Dictionary.com, https://www.dictionary.com/browse/fraud, dicapai pada 22 Julai 2019.

18 Merriam-Webster, https://www.merriam-webster.com/dictionary/fraud, dicapai pada 22 Julai 2019.

19 Merriam-Webster, https://www.merriam-webster.com/dictionary/fraud, dicapai pada 22 Julai 2019.

20 Merriam-Webster, https://www.merriam-webster.com/dictionary/fraud, dicapai pada 22 Julai 2019; The World Book Dictionary, vol. 1, 848.

${ }^{21}$ Merriam-Webster, https://www.merriam-webster.com/dictionary/fraud, dicapai pada 22 Julai 2019.

22 Dictionary.com, https://www.dictionary.com/browse/fraud, dicapai pada 22 Julai 2019; The World Book Dictionary, vol. 1, 848.

23 Merriam-Webster, https://www.merriam-webster.com/dictionary/fraud, dicapai pada 22 Julai 2019.

24 Dictionary.com, https://www.dictionary.com/browse/fraud, dicapai pada 22 Julai 2019.

25 Merriam-Webster, https://www.merriam-webster.com/dictionary/fraud, dicapai pada 22 Julai 2019.

26 Merriam-Webster, https://www.merriam-webster.com/dictionary/fraud, dicapai pada 22 Julai 2019; Klass, G., 'Meaning, Purpose, and Cause in the Law of Deception,' The Georgetown Law Journal, vol. 100 (2012): 449-496.

27 Merriam-Webster, https://www.merriam-webster.com/dictionary/fraud, dicapai pada 22 Julai 2019. 
suatu tindakan untuk menipu iaitu satu tingkah laku salah yang diiktiraf oleh undang-undang.

Penipuan boleh dituntut melalui tort, jenayah dan kontrak. Bagi undangundang tort, tuntutan penipuan adalah berasaskan undang-undang common law dan meliputi kes-kes yang telah diputuskan oleh mahkamah sebelum ini sama ada di England atau di Malaysia. Perkara ini boleh dilihat dalam kes seperti PT Gunung Madu Plantations v. Muhammad Jimmy Goh Mashun ${ }^{28}$, YapSauChoon@Yap Bee Yong \& Anorv. Cheong Hong Mun \& Ors, ${ }^{29}$ Bacom Enterprises Sdn Bhd v. Jong Chuk \& Ors. ${ }^{30}$

Di Malaysia, peruntukan undang-undang berkaitan penipuan ada di sebut dalam seksyen 24 Kanun Keseksaan (Akta 574), iaitu seseorang yang melakukan sesuatu dengan niat menyebabkan keuntungan yang salah atau kerugian kepada seseorang yang lain dikatakan melakukannya secara tidak jujur. Manakala dalam seksyen 25 Kanun Keseksaan (Akta 574) menyatakan bahawa seseorang itu dikatakan melakukan penipuan sekiranya dia melakukan sesuatu dengan niat untuk menipu. Selain itu, di bawah seksyen 415 Kanun Keseksaan (Akta 574) menyatakan bahawa seseorang dikatakan melakukan penipuan sekiranya dia menipu atau tidak jujur mendorong seseorang untuk menyerahkan harta kepada orang lain, atau untuk bersetuju bahawa orang lain itu akan menyimpan hartanya. Menurut peruntukan yang sama, seseorang itu dikatakan melakukan penipuan sekiranya dia secara berniat mendorong seseorang untuk melakukan sesuatu atau tidak melakukan sesuatu jika dia tidak ditipu, atau tindakan atau peninggalan yang menyebabkan atau kemungkinan akan menyebabkan kerosakan atau kemudaratan kepada seseorang dalam badan, fikiran, reputasi, atau harta benda. Ini bermaksud, sesuatu perbuatan itu dikatakan sebagai penipuan apabila dilakukan secara tidak jujur, berniat jahat dan memudaratkan orang lain.

Selain itu, penipuan juga ada disebut dalam seksyen 17 Akta Kontrak 1950 yang membawa maksud perbuatan yang dilakukan oleh pihak yang berkontrak dengan niat untuk menipu satu pihak lagi atau mendorong seseorang untuk membuat kontrak termasuk fakta yang tidak benar oleh pihak yang tidak mempercayai kebenarannya, penyembunyian fakta oleh pihak yang tahu dan percaya dengan fakta tersebut, apa-apa janji yang dibuat tanpa niat untuk

28 PT Gunung Madu Plantations v. Muhammad Jimmy Goh Mashun [2018] 3 MLJ 53.

29 Yap Sau Choon@Yap Bee Yong \& Anor v.Cheong Hong Mun \& Ors [2016] MLJU 1203.

30 Bacom Enterprises Sdn Bhd v. Jong Chuk \& Ors [2011] MLJU 481. 
menepatinya, apa-apa perbuatan menipu yang lain dan apa-apa perbuatan yang diisytiharkan sebagai penipuan oleh undang-undang.

Peruntukan undang-undang di Malaysia meletakkan penipuan sebagai kesalahan di bawah undang-undang jenayah dan sivil tetapi tuntutan atau dakwaan boleh dibuat bergantung kepada bentuk kesalahan sebagaimana yang disebut sama ada di bawah peruntukan Kanun Keseksaan (Akta 574) atau Akta Kontrak 1950. Bagi kes penipuan dalam forensik, sekiranya seseorang pakar forensik yang dipanggil ke mahkamah memberikan keterangan yang tidak jujur dan menyebabkan kerugian kepada pihak lain, maka pakar tersebut boleh didakwa di bawah peruntukan seksyen 24, seksyen 25, seksyen 415 Kanun Keseksaan (Akta 574) atau seksyen 17 Akta Kontrak 1950. Perkara ini ditentukan berdasarkan klausa yang diperincikan di bawah peruntukan undang-undang tersebut. Sekiranya pakar forensik tersebut membuat kontrak untuk melakukan penipuan, maka Seksyen 17 Akta Kontrak 1950 adalah terpakai. Sekiranya tidak ada kontrak yang dibuat, maka pihak yang ditipu boleh membuat dakwaan dan tuntutan di bawah seksyen 24, seksyen 25 dan seksyen 415 Kanun Keseksaan (Akta 574).

\section{Penipuan menurut Perundangan Islam}

Perkataan penipuan dalam Bahasa Arab disebut dengan beberapa perkataan sinonim, antaranya ghurur, ${ }^{31}$ hilah, ${ }^{32}$ khianat, ${ }^{33}$ ghisy, ${ }^{34}$ khida'. ${ }^{35}$ Berdasarkan beberapa perkataan ini, maka dalil daripada ayat al-Quran yang menyatakan berkaitan penipuan dapat dikenal pasti. Terdapat dalil-dalil yang menjelaskan tentang tegahan menipu atau menyembunyikan kebenaran dalam urusan manusia. Ini jelas menunjukkan bahawa penipuan merupakan suatu bentuk salah laku yang sangat dilarang dalam perundangan Islam. Perbuatan menyembunyikan kebenaran dan mencampurkan fakta yang betul dan fakta yang salah juga dianggap sebagai penipuan menurut perundangan Islam. Firman Allah SWT:

31 The Hans Wehr Dictionary of Modern Written Arabic, $3^{\text {rd }}$ ed. (New York: Spoken Language Services, Inc., 1976), 667.

32 Munir Ba'albaki (trans.), al-Mawrīd: A Modern English-Arabic Dictionary, $39^{\text {th }}$ ed. (Bayrūt: Dār al-'Ilm li al-Malayīn, 2005), 496.

33 The Hans Wehr Dictionary of Modern Written Arabic, 266.

34 The Hans Wehr Dictionary of Modern Written Arabic, 674; Munir Ba'albaki (trans.), al-Mawrìd: A Modern English-Arabic Dictionary, $39^{\text {th }}$ ed., 800.

35 The Hans Wehr Dictionary of Modern Written Arabic, 229; Munir Ba'albaki (trans.), al-Mawrid: A Modern English-Arabic Dictionary, $39^{\text {th }}$ ed., 505. 


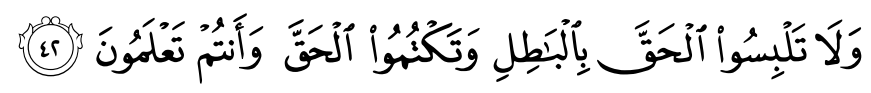

"Dan janganlah kamu campur adukkan yang benar itu dengan yang salah, dan kamu sembunyikan yang benar itu pula padahal kaтu semua mengetahuinya."

(Surah al-Baqarah, 2: 42)

Seterusnya, Allah SWT berfirman:

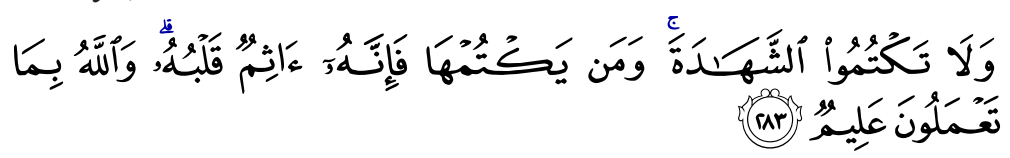

"Dan janganlah kamu (wahai orang-orang yang menjadi saksi) menyembunyikan perkara yang dipersaksikan itu. Dan sesiapa yang menyembunyikannya, maka sesungguhnya ia adalah orang yang berdosa hatinya. Dan (ingatlah), Allah sentiasa mengetahui akan apa yang kamu kerjakan."

(Surah al-Baqarah, 2: 283)

Kedua-dua ayat ini menjelaskan bahawa sesiapa yang mengetahui kebenaran tidak boleh menyembunyikannya. Oleh itu, sekiranya seseorang diminta untuk hadir ke mahkamah sebagai saksi, maka dia wajib hadir dan ditegah untuk melakukan apa-apa bentuk penipuan. Saksi juga tidak boleh memberikan keterangan palsu kerana shahädah/qawl al-zur termasuk dalam kategori dosa besar. ${ }^{36}$ Allah SWT berfirman:

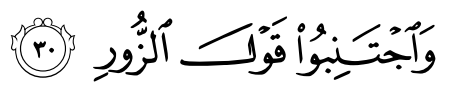

"Serta jauhilah perkataan yang dusta."

(Surah al-Hajj, 22: 30)

Larangan memberikan keterangan palsu atau menipu juga terdapat dalam hadis. Daripada Abu Bakrah RA bahawa Rasulullah SAW bersabda:

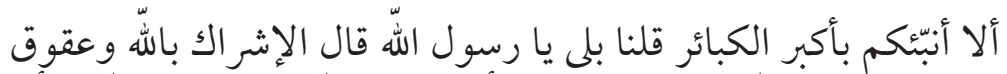

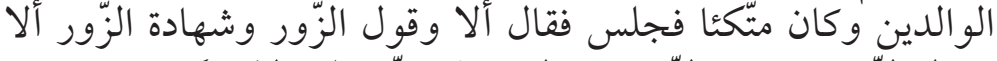

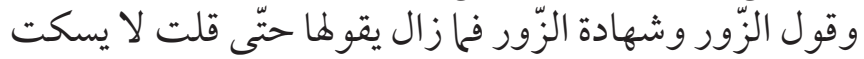

36 Zaydān, 'Abd al-Karīm, Niẓām al-Qaḍā' (Bayrūt, Lubnan: Mu'assasah al-Risālah, 2002), 167. 
"Tidak mahukah aku beritahukan kepada kalian sesuatu yang termasuk dari dosa besar? Kami menjawab; "Tentu wahai Rasulullah." Beliau bersabda: "Menyekutukan Allah dan menderhakai kedua orang tua." -ketika itu baginda tengah bersandar, kemudian duduk lalu melanjutkan sabdanya: "Perkataan dusta dan kesaksian palsu, perkataan dusta dan kesaksian palsu." Beliau terus saja mengulanginya hingga saya mengira beliau tidak akan berhenti." 37

Dalam hadis ini, Rasulullah SAW menyamakan kesalahan menyekutukan Allah SWT dan menderhaka kepada orang tua dengan kesalahan mengeluarkan perkataan dusta dan memberikan kesaksian palsu. Ini menunjukkan bahawa berat kesalahan menipu adalah sesuatu yang tidak dapat dipertikaikan menurut perundangan Islam. Seseorang saksi yang menipu boleh dikenakan hukuman yang berat sekiranya dia berniat untuk melakukan penipuan ketika memberikan keterangan..$^{38}$ Islam menyatakan tentang akibat daripada penipuan yang dilakukan oleh seseorang dalam apa jua urusan sepertimana firman Allah SWT di dalam al-Quran:

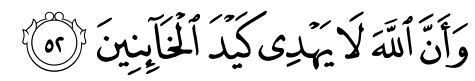

"Dan bahawa Allah tidak menjayakan tipu daya orang-orang yang khianat."

(Surah Yūsuf, 12: 52)

Pada zaman Rasulullah SAW, pernah berlaku satu peristiwa besar iaitu peristiwa al-Ifki (tuduhan dusta terhadap ' $\overline{\mathrm{A}}$ 'ishah). Peristiwa al-Ifki merupakan satu peristiwa penipuan yang dilakukan oleh orang-orang munafiq terhadap ' $\overline{\mathrm{A}}$ 'ishah RA, iaitu tuduhan melakukan zina dengan seorang sahabat yang bernama Sofwan Bin Mu'attol RA. Perkara ini menimbulkan kacau bilau dalam kalangan masyarakat di Madinah pada ketika itu. Ada di antara sahabat yang tidak mempercayai berita tersebut. Ada juga yang tidak mengeluarkan apa-apa pendirian dan ada juga yang mempercayai bahawa ' $\bar{A}$ ' 'ishah RA benarbenar berzina dengan Safwan Ibn Mu'ațtal. Keadaan ini berlarutan sehingga sebulan lamanya sehingga Allah menurunkan ayat ke 11 daripada Surah al-Nur membebaskan ' $\bar{A}$ ' ishah daripada tuduhan jahat kaum munafiq. Seterusnya, Allah SWT menerangkan tentang hukuman terhadap orang yang melemparkan

\footnotetext{
37 Al-Bukhārī, Muștafāa al-Dhahabī, Șahīḥ al-Bukhārī (Qāhirah: Dār al-Ḥadīth, 2000), 138, no. hadis 5976.

38 'Ayman Muḥammad 'Al̄̄, Shahādah Ahl al-Khibrah wa Ahkāmuhā (Jurdān: Dār al-Hamīd, 2008), 52.
} 
tuduhan (qazaf) terhadap wanita yang suci dengan menghukumnya dengan hukuman sebatan. ${ }^{39}$

Peristiwa yang berlaku ini menunjukkan bahawa penipuan yang dibuat terhadap ' $\bar{A}$ ' ishah RA menyebabkan tersebarnya berita buruk yang merosakkan maruah isteri Rasulullah SAW. Walaupun penipuan dilakukan oleh beberapa orang sahaja, namun ia cukup memberikan kesan yang besar dalam kalangan masyarakat dan masih diingati sehingga ke hari ini. Maka, hukuman yang qazaf yang dikenakan adalah wajar bagi menginsafkan pelaku jenayah tersebut.

Justeru, dapat disimpulkan bahawa penipuan adalah satu perbuatan dosa besar dan ditegah menurut perundangan Islam. Perbuatan menipu meliputi pelbagai cara termasuk menyembunyikan kebenaran, mencampurkan fakta yang betul dan fakta yang salah dan memberikan keterangan palsu. Seseorang yang didapati melakukan penipuan sewajarnya mendapat hukuman yang berat kerana penipuan yang dilakukan boleh menjejaskan seseorang individu dalam masyarakat.

\section{LIABILITI PENIPUAN DALAM UNDANG-UNDANG TORT DAN PERUNDANGAN ISLAM}

Penipuan dalam undang-undang tort merangkumi tuntutan sivil oleh seseorang yang ingin menuntut ganti rugi akibat kerosakan atau kerugian yang ditanggung. Begitu juga dalam perundangan Islam, tuntutan boleh dibuat sekiranya pihak yang ditipu mengalami penganiayaan akibat daripada penipuan. Di bawah undang-undang tort, tanggungan boleh dikenakan kepada pelakunya jika mahkamah mendapati wujud liabiliti. Manakala dalam Islam, penipuan jelas diketahui sebagai haram dan dilarang. Namun, liabiliti kepada pelakunya kurang dibincangkan oleh literatur terdahulu. Justeru, seterusnya akan dibincangkan berkaitan liabiliti penipuan dalam undang-undang tort dan juga Perundangan Islam.

\section{Liabiliti Penipuan dalam Undang-undang Tort di Malaysia}

Undang-undang tort merupakan undang-undang sivil yang berkaitan dengan tuntutan daripada pihak persendirian akibat kecederaan atau kerugian yang disebabkan oleh pihak lain. Antara perbuatan salah yang boleh dituntut di bawah undang-undang tort adalah penipuan atau disebut sebagai tort penipuan. Penipuan juga boleh berlaku dalam kes jenayah dan juga kes-kes sivil lain iaitu

39 Sayyid Quṭb, F̄̄ Zilāl al-Qur'ān (Bayrūt: Dār al-Shurūq, 2003), 2486. 
dalam keadaan pihak yang ditipu tidak mengetahui bahawa ada pihak lain yang melakukan penipuan terhadapnya. Sekiranya penipuan yang dilakukan dikenal pasti, maka pihak yang melakukan penipuan tersebut mempunyai liabiliti ke atas pihak yang ditipu.

Contohnya, apabila seseorang membuat tuntutan insurans palsu kepada syarikat insurans dalam kes kemalangan motor. Sekiranya dia mendakwa bahawa pihak lain telah merosakkan kenderaannya dalam perlanggaran sedangkan sebenarnya kerosakan itu disebabkan kesalahan diri sendiri. Kenyataan penipuan yang diberikan olehnya menyebabkan syarikat insurans perlu membayar insurans kepadanya, maka dia mempunyai liabiliti kepada syarikat insurans tersebut di bawah undang-undang tort penipuan. ${ }^{40}$ Ini bermaksud, seseorang yang menipu untuk mendapatkan bayaran insurans daripada syarikat insuran bertanggungan untuk membayar semula ganti rugi tersebut kepada syarikat insurans.

Menurut Seksyen 10 subseksyen (1) Akta Undang-undang Sivil 1956, kerosakan atau kerugian yang ditanggung oleh sesiapa sahaja akibat daripada tort (sama ada jenayah atau tidak), penghakiman dipulihkan terhadap manamana pelaku yang bertanggungan dan kerosakan itu tidak menjadi penghalang kepada tindakan terhadap mana-mana orang lain yang mempunyai tanggungan sebagai pelaku bersama untuk kerosakan yang sama. Sekiranya lebih dari dua tindakan dibawa bagi kerosakan itu oleh mangsa untuk manfaat sesiapa pun, maka pelaku bertanggungan atas kerosakan tersebut sejumlah yang boleh diperolehi berdasarkan pertimbangan yang diberikan dalam tindakan tersebut dengan ganti rugi keseluruhan tidak boleh secara keseluruhan melebihi jumlah ganti rugi yang diberikan oleh penghakiman yang pertama kali diberikan. Selain daripada apa yang diputuskan dalam penghakiman pertama, penuntut tidak perlu membayar kos melainkan mahkamah berpandangan bahawa terdapat asas yang munasabah untuk tindakan.

Dalam kes tuntutan insurans palsu yang dibuat daripada kemalangan motor, ganti rugi boleh dituntut bagi kerosakan berkaitan masa yang diambil oleh syarikat insurans dan penyiasat untuk menangani dan menyiasat tuntutan tersebut; pengeluaran yang dikeluarkan oleh syarikat insurans; kos pembaikan kenderaan pemegang polisi yang membuat tuntutan palsu; pembayaran yang telah dibuat kepada individu melalui polisi mereka. ${ }^{41}$

$\overline{40}$ Trevelyan, L., 'Civil/Commercial Fraud, Fraudulent Misrepresentation and the Tort of Deceit,' https://www.inbrief.co.uk/offences/fraud/, dicapai pada 3 Disember 2020.

41 Trevelyan, L., Civil/Commercial Fraud, Fraudulent Misrepresentation and the Tort of Deceit.' 
Bagi kes yang melibatkan pakar forensik yang dipanggil untuk memberikan keterangan di mahkamah, prosesnya bermula dengan pengumpulan bukti sebagai keterangan, kemudian akan diikuti dengan analisis yang dilakukan menggunakan teknik yang telah ditetapkan dan telah dibuktikan berdasarkan pengalaman makmal sains sebelum itu. ${ }^{42}$ Pakar forensik yang dipanggil ke mahkamah perlu mengenal pasti hasil analisis dan memberi pandangan berkaitan bukti yang dibawa ke mahkamah. ${ }^{43}$ Sekiranya ditanya tentang hasil analisis, pakar tersebut mestilah meyakinkan mahkamah bahawa dia telah menjaga bahan bukti bermula daripada ia ditemui sehingga siap dianalisis. ${ }^{44}$ Setiap proses yang diikuti oleh seseorang pakar forensik perlu diteliti kerana penentuan liabiliti ke atas pihak yang bertanggungan adalah bergantung kepada setiap proses ini. Sekiranya dikesan penipuan dalam mana-mana proses, maka tanggungan akan dikenakan kepada pelaku tersebut.

Pakar forensik mestilah bersedia untuk memberikan penerangan tentang teknik yang digunakan ketika menganalisis bahan bukti dan memberikan pandangan dan penjelasan hasil analisis bahan bukti tersebut. ${ }^{45}$ Keterangan yang diberikan oleh pakar ini memerlukan satu demonstrasi yang biasa dan disokong oleh gambar. Contohnya, gambar perbezaan peluru, sarung peluru, besi dan sebagainya. ${ }^{46}$ Manakala pandangan yang diberikan pula menggambarkan pengetahuannya dalam bidang tersebut dan boleh juga menyatakan pengalamannya berdasarkan kes yang hampir sama sebelum itu. ${ }^{47}$ Sekiranya pakar tersebut melakukan penipuan, maka liabiliti bagi penipuan akan ditanggung oleh pakar itu jika penipuan berjaya dibuktikan.

Oleh itu, keterangan pakar forensik boleh diterima oleh kedua-dua pihak dalam mahkamah sama ada pihak pendakwa atau pembela dan boleh juga ditolak. Namun, adalah menjadi kebiasaan dalam sesuatu kes, laporan yang dikemukakan oleh pakar forensik ditolak atau dinafikan oleh salah satu

42 Eckert, W. G., 'Scientific Evidence in Court,' 69.

43 Ozkul, F. U. \& Pamukcu, A., 'Fraud Detection and Forensic Accounting,' dalam Emerging Fraud: Fraud Cases from Emerging Economies, ed. Caliyurt, K. \& Idowu, S. O. (Berlin Heidelberg: Springer, 2012), 19-41; Eckert, W. G., 'Scientific Evidence in Court,' 80.

44 Eckert, W. G., 'Scientific Evidence in Court,' 69.

45 Ozkul, F. U. \& Pamukcu, A., 'Fraud Detection and Forensic Accounting,' 19-41; Eckert, W. G., 'Scientific Evidence in Court,' 75.

46 Eckert, W. G., 'Scientific Evidence in Court,' 76.

47 Eckert, W. G., 'Scientific Evidence in Court,' 76; Poklis, A., 'Forensic Toxicology', dalam Introduction to Forensic Sciences, ed. Eckert, W. G. (New York: Elsevier, 1992), 131. 
pihak. ${ }^{48}$ Penolakan dan penafian ini menunjukkan bahawa penipuan tort berkemungkinan wujud dalam keterangan pakar menyebabkan timbul keraguan dalam penerimaan keterangan tersebut. Apabila perkara ini berlaku, maka mangsa boleh menuntut ganti rugi dan pakar tersebut adalah bertanggungan untuk membayar ganti rugi kepada mangsa penipuan.

Antarakeadaanyang berkaitan dengan penipuanadalah dalampembentangan bukti forensik oleh pakar. Pembentangan bukti forensik yang mengelirukan dapat dikenal pasti sekiranya pakar yang mengumpulkan dan mengenal pasti bukti adalah orang yang berbeza dengan pakar yang menganalisis bukti. Perkara ini menunjukkan bahawa orang yang sepatutnya memberikan keterangan iaitu orang yang terlibat dengan proses teknikal bahan bukti perlu hadir untuk memberikan keterangan. Pakar forensik yang mengumpulkan bukti sebagai saksi tidak boleh memberikan keterangan berdasarkan apa yang dianalisis oleh pakar forensik lain. Ini kerana apabila keterangan diberikan oleh orang yang tidak mengendalikan bahan bukti, maka keterangan itu mungkin boleh mengelirukan atau boleh berlaku penipuan dalam keterangan tersebut. Dalam keadaan ini, sekiranya pakar forensik itu didakwa melakukan penipuan, maka dia bertanggungan untuk membayar ganti rugi kepada mangsa.

Terdapat juga keadaan yang dikatakan sebagai berlakunya penipuan iaitu keterangan pakar forensik yang tidak jujur. Walaupun sains adalah sesuatu yang bersifat objektif dan tiada unsur bias, ${ }^{49}$ namun tidak dapat dinafikan bahawa manusia mungkin melakukan kesilapan. Penipuan boleh berlaku dalam kalangan pakar psikiatri apabila memberikan keterangan di mahkamah berkaitan pesakit. Mereka mungkin memberikan kenyataan yang tidak jujur iaitu bercakap tanpa mengambil berat akan kebenaran fakta yang diberitahu. ${ }^{50}$ Ini bermaksud, pakar tersebut tidak meneliti apa yang diceritakan oleh pesakitnya dan memberikan keterangan yang tidak jujur di mahkamah tentang pesakitnya. Sekiranya perkara ini berlaku, liabiliti akan dikenakan kepada pakar tersebut kerana boleh didakwa dengan dakwaan penipuan tort.

Selain itu, dakwaan penipuan tort boleh berlaku terhadap keterangan bias yang dikemukakan oleh seseorang pakar di mahkamah. Ini terjadi apabila bayaran yang diberikan bagi perkhidmatan pakar yang menguntungkan untuk tempoh perbicaraan. ${ }^{51}$ Seseorang pakar yang dipanggil ke mahkamah

\footnotetext{
48 Wall, W. Forensic Science in Court: The Role of the Expert Witness, 92.

49 Cole, S. A, 'Forensic Science and Wrongful Convictions: From Exposer to Contributor to Corrector,' New England Law Review, vol. 46 (2011): 711-736.

50 Spence, S. A., 'Reading about Deception,' 146-149.

51 Slovenko, R., 'Evidential Value of Therapist Versus Forensic Expert Testimony', Journal of Psychiatry and Law, vol. 25/1 (1997): 5-32.
} 
dibayar oleh pihak yang memanggilnya sebagai saksi. Maka, tidak mustahil untuk berlaku bias dalam kalangan pakar kerana bayaran akan mempengaruhi pendapat seseorang pakar. Sekiranya bias ini dilakukan oleh pakar, maka pakar tersebut adalah bertanggungan untuk membayar ganti rugi kepada mangsa dalam kes tersebut.

Dalam kes Theow Say Kow@ Teoh Kiang Seng, Henry v. Graceful Frontier Sdn Bhd \& Ors ${ }^{52}$ dakwaan wujudnya tandatangan palsu dalam dokumen yang dijadikan sebagai bukti kes diragui. Kedua-dua pihak, plaintif dan defenden membawa saksi pakar forensik untuk mengesahkan tandatangan tersebut. Namun, hakim hanya menerima salah satu pandangan pakar sahaja tanpa mengambil kira fakta lain sedangkan keputusan tidak wajar dibuat semata-mata dengan mendengar pandangan pakar sahaja. Maka, perayu telah membuat rayuan berkaitan perkara ini. Hakim mahkamah rayuan memutuskan bahawa mahkamah terdahulu khilaf dalam menerima keterangan pakar forensik tersebut kerana pakar tersebut telah dibayar untuk memberikan keterangan yang berpihak kepada pihak yang membayarnya. Pakar forensik yang memberikan keterangan yang tidak jujur tersebut bertanggungan untuk membayar ganti rugi atas kerugian yang disebabkan oleh keterangannya.

Justeru, dapat disimpulkan bahawa liabiliti dalam penipuan menurut undang-undang tort ditanggung oleh pelaku kesalahan tersebut sama ada dalam kes pernyataan palsu atau tindakan menipu. Ini kerana kedua-dua keadaan ini dilakukan dengan niat supaya pihak yang ditipu akan bertindak berdasarkan pernyataan atau tindakan tipu tersebut. Dengan demikian, pihak yang ditipu akan tertipu dan mengalami kerosakan atau kerugian disebabkan itu. Sekiranya kes sebegini terjadi, pihak ditipu boleh menuntut ganti rugi.

\section{Liabiliti Penipuan dalam Perundangan Islam}

Dalam perundangan Islam, para fuqaha mempunyai pandangan yang berbeza berkenaan dengan tanggungan yang disebabkan oleh perbuatan menipu. Para fuqaha mazhab Mālikī bersepakat mengatakan bahawa tanggungan akan dikenakan ke atas penipuan yang dilakukan secara tindakan atau kelakuan seperti mewarnakan pakaian lama supaya pakaian itu kelihatan baru, mengotorkan tangan seorang hamba dengan dakwat untuk menunjukkan bahawa hamba itu pandai menulis dan membaca, dan sebagainya.

52 Theow Say Kow @ Teoh Kiang Seng, Henry v. Graceful Frontier Sdn Bhd \& Ors [2020] MLJU 57. 
Mengikut mazhab Hanafĩ pula, penipu tidak akan bertanggungan ke atas sebarang kerugian yang dialami oleh pihak kena tipu, kecuali dalam keadaan penipuan berlaku dalam urusan yang bersyarat. Ini boleh berlaku seperti dalam kes Ali berkahwin dengan Aminah atas asas Ahmad telah mengatakan kepada Ali bahawa Aminah itu bukan seorang hamba. Hasil dari perkahwinan itu Aminah melahirkan seorang anak, kemudian muncul pihak lain yang membuktikan bahawa Aminah sebenarnya seorang hamba. Tuan punya hamba tersebut berhak memperolehi ganti rugi daripada Ali. Walau bagaimanapun, ganti rugi itu ditujukan kepada Ahmad, kerana Ahmad dianggap sebagai penipu yang telah menyebabkan kerosakan atau kerugian kepada tuan punya hamba tersebut. ${ }^{53}$

Para fuqaha mazhab Hanbali bersetuju dengan pendapat para fuqaha mazhab Hanafĩ ketika membincangkan kes penipuan ini. Ini dapat dijelaskan dengan contoh yang berikut. Jika A membeli sekeping tanah daripada B, lalu A menanam tanaman atau membina bangunan di atasnya dan selepas itu $\mathrm{C}$ muncul dengan menuntut bahawa tanah tersebut adalah miliknya. B bertanggungan ke atas kerugian yang dialami oleh A disebabkan penipuan yang dilakukannya. $\mathrm{B}$ bertanggungan membayar ganti rugi terhadap semua kerugian yang dialami oleh A, iaitu perbelanjaan membina bangunan, menanam tanaman, pembayaran untuk meruntuhkan bangunan, mencabut tanaman dan sebagainya. ${ }^{54}$

Para fuqaha mazhab Hanbali juga membebankan tanggungan ke atas penipu yang menyebabkan kerugian kepada pihak lain, yang disebabkan daripada tindakannya menyembunyikan atau tidak mengisytiharkan kerosakan atau kecacatan yang terdapat pada sesuatu barangan dengan tujuan untuk menarik perhatian pihak lain mempercayai bahawa barangan tersebut dalam keadaan baik. Kes-kes yang boleh dihubungkan dalam perbincangan ini ialah seperti mewarnakan atau mendandan rambut seorang hamba perempuan supaya kelihatan muda, melakukan solekan pada mukanya, dan sebagainya. Tindakan yang dilakukan itu bertujuan untuk memperdayakan orang ramai yang ingin mendapatkan hamba bagi melakukan sesuatu pekerjaan. Hamba perempuan itu kelihatan muda dan masih boleh berkerja kuat, sedangkan keadaan sebenar hamba perempaun itu adalah sebaliknya. Sekiranya timbul tuntutan penipuan daripada pembeli kepada penjual, maka penjual hamba tersebut akan bertanggungan kerana penipuan yang dilakukan itu. Penjual telah melakukan

53 Al-Baghdadī, Majmā' al-Ḍamanāt (Qāhirah: al-Maṭba'ah al-Khayriyyah bi alJamāliyyah, 1890), 454.

54 Ibn Duwayyan, Manār al-Sabīl, vol. 1 (Bayrūt: al-Maktabah al-Islāmī, 1984), 436-437; al-Buhūtī, Manșūr Ibn Yūnus Ibn Idrīs, Sharḥ Muntahā al-Irādāt, vol. 2 (Bayrūt: 'Alam al-Kutub, t.t.), 417. 
perdayaan yang mendorong pembeli supaya membeli hamba tersebut dengan menaruh penuh kepercayaan bahawa hamba itu masih muda dan kuat berkerja. Pendapat ini bersamaan dengan pendapat Imam Abū Hanīfah dan al-Shāfi'‘̄. Walau bagaimanapun, Abū Hanīfah tidak bersetuju dengan kes mendandan atau mengerinting rambut. Menurut pendapat beliau, walaupun kes ini boleh dianggap sebagai penipuan, tetapi kecacatan tidak berlaku. ${ }^{55}$

Seterusnya, pihak yang kena tipu juga boleh menuntut ganti rugi terhadap kerugian yang dialaminya akibat daripada tindakan penipuan oleh seseorang seperti dalam kes baju lama diwarnakan baru supaya kelihatan baru, barang yang rendah kualiti dicampur dengan yang baik kualiti supaya dapat dinaikkan harganya, dan sebagainya. Ibn Rajab mengemukakan kaedah bahawa seseorang yang mendorong orang lain dengan niat menipu supaya melakukan sesuatu perbuatan, pihak yang mendorong itu dikira penipu dan bertanggungan terhadap tindakan penipuannya. Contohnya, seseorang membuat pengakuan dengan niat untuk menipu bagi mendorong seorang lelaki berkahwin dengan seorang wanita dengan menyatakan wanita itu bukan seorang hamba, sedangkan wanita tersebut adalah seorang hamba. Pihak yang telah membuat pengakuan yang tidak benar itu dianggap sebagai penipu dan bertanggungan dalam kes ini. Tuan punya hamba wanita tersebut berhak mendapat ganti rugi atas kerugian yang berlaku kepada hambanya. ${ }^{56}$

Selain itu, para fuqaha mazhab al-Shāfi ‘ 1 mempunyai pendapat yang berbeza berkaitan tanggungan penipuan yang boleh dikenakan dalam kes penipuan. Pendapat yang masyhur menyatakan bahawa tanggungan dibebankan atas pihak yang ditipu. Mereka mengemukakan teori: apabila berhimpun pihak yang menipu dan pihak yang melakukan kerosakan (iaitu pihak yang kena tipu), keutamaan diberikan kepada pihak yang melakukan kerosakan (idhä ijtama' $a$ al-ghurūr wa al-mubāsharah, qudimat al-mubāsharah). Ini memberi maksud bahawa apabila pihak yang kena tipu itu merupakan seorang mubasharah atau pihak yang melakukan kerosakan, maka tanggungan dibebankan ke atasnya. Sebagai contoh, A merampas sekeping roti daripada B, lalu roti itu diberikan kepada seorang tetamu. Tetamu itu akan bertanggungan jika dia memakan roti tersebut dalam keadaan mengetahui bahawa roti itu adalah roti yang dirampas daripada seseorang. Walau bagaimanapun, jika tetamu tersebut tidak mengetahuinya, fuqaha berselisih pendapat dalam hal ini. Pendapat mereka boleh dipecahkan kepada dua, iaitu pendapat pertama: tanggungan dibebankan ke atas perampas, kerana dia telah menipu tetamu tersebut dengan

55 Ibn Qudāmah, Ab̄̄ Muḥammad 'Abd Allāh Ibn Ahmad Ibn Muhammad alMaqdisī, al-Mughnī, vol. 4 (Bayrūt: Dār al-Manar, 1947), 141.

56 Ibn Rajāb, al-Qawā 'id fí al-Fiqh al-Islāmī (Bayrūt: Dār al-Jīl, 1988), 226. 
menghidangkan roti itu. Manakala pendapat kedua: tanggungan dibebankan ke atas tetamu yang telah memakan roti tersebut, kerana dia adalah pihak yang melakukan kerosakan secara langsung kepada roti itu dan juga pihak yang telah mendapat faedahnya. Oleh itu, jika tetamu itu membayar ganti rugi kepada pemilik asal roti tersebut, perampas tidak lagi bertanggungan ke atas pembayaran itu, sebaliknya jika perampas yang membayarnya, tetamu masih lagi bertanggungan. Pendapat ini dianggap sebagai pendapat yang masyhur dan jelas $(a z h \bar{a} r) .{ }^{57}$

Berasaskan kepada perbincangan, adalah jelas bahawa tanggungan ganti rugi dalam kes penipuan melalui tindakan (al-ghurūr al-fi'l) mewujudkan bebanan tanggungan yang mesti dibayar oleh pihak yang melakukan penipuan. Hal ini berdasarkan pendapat para fuqaha kecuali dalam mazhab al-Shāfi 'ī sahaja, iaitu fuqaha mazhab yang mempunyai perbezaan pendapat dalam kes pemberian makanan yang dirampas kepada seseorang atau tetamu.

\section{KESIMPULAN}

Berdasarkan perbincangan yang telah dibahaskan, dapat disimpulkan bahawa kesalahan penipuan merupakan satu tingkah laku salah menurut perundangan Islam dan undang-undang tort. Kesalahan penipuan dalam forensik berlaku dalam beberapa keadaan tertentu iaitu dalam pembentangan bukti forensik oleh pakar dan penipuan dalam keterangan pakar forensik yang tidak jujur. Liabiliti bagi kesalahan penipuan tort perlu diteliti sebelum memberikan tanggungan kepada pelaku yang bersalah. Maka, langkah berhati-hati perlu diambil sama ada oleh pakar forensik yang mengendalikan bahan bukti dan memberikan keterangan di mahkamah serta para pengamal undang-undang sama ada hakim atau peguam dalam menguruskan bahan bukti yang berkaitan forensik. Kajian ini diharap agar dapat memberi implikasi kepada badan perundangan dan kehakiman, pengamal undang-undang dan kepada pakar forensik yang dipanggil ke mahkamah untuk memberikan keterangan.

\section{RUJUKAN}

Abdul Basir Mohamad, Undang-Undang Tort Islam (Kuala Lumpur: Dewan Bahasa dan Pustaka, 2009).

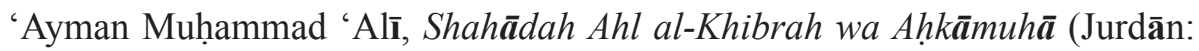
Dār al-Hamīd, 2008).

57 Al-Ghazālī, al-Wajīz, vol. 1 (Bayrūt: Dār al-Ma‘rifah, 1979), 207. 
Al-Baghdadī, Majmā' al-Ḍamanāt (Qāhirah: al-Mațba'ah al-Khayriyyah bi al-Jamāliyyah, 1890).

Al-Buhūtī, Manșūr Ibn Yūnus Ibn Idrīs, Sharh Muntahā al-Irādāt, vol. 2 (Bayrūt: 'Alam al-Kutub, t.t.).

Al-Bukhārī, Muṣṭafā al-Dhahabī, Șaḥịh al-Bukhārī (Qāhirah: Dār al-Hadīth, 2000).

Cole, S. A, 'Forensic Science and Wrongful Convictions: From Exposer to Contributor to Corrector,' New England Law Review, vol. 46 (2011): 711-736.

Dictionary.com, https://www.dictionary.com/browse/fraud, dicapai pada 22 Julai 2019.

Eckert, W. G., Introduction to Forensic Sciences, ed. Eckert, W. G. (New York: Elsevier, 1992).

Al-Ghazālī, al-Wajīz, vol. 1 (Bayrūt: Dār al-Ma'rifah, 1979).

Ibn Duwayyan, Manār al-Sabīl, vol. 1 (Bayrūt: al-Maktabah al-Islāmī, 1984).

Ibn Qudāmah, Abī Muḥammad 'Abd Allāh Ibn Aḥmad Ibn Muḥammad alMaqdisī, al-Mughnī, vol. 4 (Bayrūt: Dār al-Manar, 1947).

Ibn Qayyim al-Jawziyyah, I'lām al-Muwaqqi 'ìn 'an Rabb al-'Ālamīn, vol. 2 (Qāhirah: Dār al-Kutub al-Hadīthah, 1969).

Ibn Rajāb, al-Qawā 'id fì al-Fiqh al-Islāmī (Bayrūt: Dār al-J̄̄l, 1988).

Klass, G., 'Meaning, Purpose, and Cause in the Law of Deception,' The Georgetown Law Journal, vol. 100 (2012): 449-496.

Munir Ba'albaki (trans.), al-Mawrīd: A Modern English-Arabic Dictionary, $39^{\text {th }}$ ed. (Bayrūt: Dār al-'Ilm li al-Malayīn, 2005).

Merriam-Webster,https://www.merriam-webster.com/dictionary/fraud, dicapai pada 22 Julai 2019.

Ozkul, F. U. \& Pamukcu, A., 'Fraud Detection and Forensic Accounting,' dalam Emerging Fraud: Fraud Cases from Emerging Economies, ed. Caliyurt, K. \& Idowu, S. O. (Berlin Heidelberg: Springer, 2012), 19-41.

Poklis, A., 'Forensic Toxicology', dalam Introduction to Forensic Sciences, ed. Eckert, W. G. (New York: Elsevier, 1992), 107-132.

Sayyid Quṭb, Fī Zilāal al-Qur'ān (Bayrūt: Dār al-Shurūq, 2003).

Shorter Oxford English Dictionary, 5th ed., vol. 1. (United States: Oxford University Press, 2002).

Slovenko, R., 'Evidential Value of Therapist Versus Forensic Expert Testimony', Journal of Psychiatry and Law, vol. 25/1 (1997): 5-32. 
Spence, S. A., 'Reading about Deception,' The Psychiatrist, vol. 34 (2010): 146-149.

The Hans Wehr Dictionary of Modern Written Arabic, $3^{\text {rd }}$ ed. (New York: Spoken Language Services, Inc., 1976).

The World Book Dictionary, vol. 1 (Chicago, United States of America: World Book, Inc. 2000).

Trevelyan, L., 'Civil/Commercial Fraud, Fraudulent Misrepresentation and the Tort of Deceit,' https://www.inbrief.co.uk/offences/fraud/, dicapai pada 3 Disember 2020.

Wall, W. Forensic Science in Court: The Role of the Expert Witness (United Kingdom: Wiley-Blackwell, 2009).

Zaydān, 'Abd al-Karīm, Niẓām al-Qaḍā' (Bayrūt, Lubnan: Mu'assasah alRisālah, 2002).

\section{Statut}

Akta Kontrak 1950.

Akta Undang-undang Sivil 1956.

Kanun Keseksaan (Akta 574).

\section{Kes}

Bacom Enterprises Sdn Bhd v. Jong Chuk \& Ors [2011] MLJU 481.

PT Gunung Madu Plantations v. Muhammad Jimmy Goh Mashun [2018] 3 MLJ 53.

Theow SayKow@Teoh Kiang Seng, Henry v. Graceful Frontier Sdn Bhd \& Ors [2020] MLJU 57.

YapSauChoon@Yap Bee Yong \& Anorv. Cheong Hong Mun \& Ors [2016] MLJU 1203. 